\title{
APLIKASI METODE IRIDOLOGI UNTUK IDENTIFIKASI STRES PADA SISWA SD, SMP DAN SMA MENGHADAPI UJIAN NASIONAL (UN) DI SUMATERA BARAT
}

\author{
Abdul Razak \\ Jurusan Biologi FMIPA Universitas Negeri Padang \\ e-mail:abdulrzk393@gmail.com
}

\begin{abstract}
The research on the application of the method Iridologi on education for the identification of stress on the elementary, junior high and high school in West Sumatra have been implemented since 2009-2011. This study aims to determine the effectiveness of methods for identification of stress Iridologi students in teaching and learning to follow the National Examination in elementary, middle and high school. So far, education experts do not have a physical examination methods stress levels of students in learning process for success in National Examination (UN). With Iridologi methods (physical examination of the iris) is easy to determine the level of stress to find a solution. Iridologi is a branch of science neurology (the science of nerves). Iridologi able to detect changes in body condition which is reflected by a smooth peripheral nerves throughout the body in humans and vertebrate animals. This study is a pioneering application of biology to solve problems in education. The subjects studied were students at 6 SMAN in 3 districts (Padang City, Sijunjung and Pesisir Selatan regency), SDN 38 students in the city of Padang and students in the district Sijunjung SMPN 9. The results in 2009 at the stress level high school students facing the UN in 2010 was 68\% and levels of stress were 32\% rate of severe stress. Subsequently, in 2010, for elementary students, $0.08 \%$ tingat mild stress, the stress level is $65.7 \%$ and $24.3 \%$ rate of severe stress. In 2011, for junior high school students found a mild $0.8 \%$ stress levels, stress levels were $59 \%$ and $32 \%$ stress level. Conclusion from three years study showed that the method Iridologi effectively demonstrated Iridologi stress levels of students from elementary, middle and high school students to follow the national examination $(U N)$.
\end{abstract}

Kata kunci: Metode Iridologi, Identifikasi Stres

\section{PENDAHULUAN}

$\mathrm{P}$ Engalaman peneliti dalam melaksanakan kegiatan pelatihan motivasi sejak tahun 2006 telah menggunakan metode Iridologi. Metode Iridologi yang digunakan dalam pelatihan motivasi berbasis otak mampu menunjukkan tingkat stress siswa di beberapa sekolah menengah negeri dan sekolah menengah swasta di Kotamadya Padang, Kabupaten Sijunjung serta Madrasah Aliyah Negeri di Kotamadya Payakumbuh.

Setelah itu, penggunaan metode Iridologi untuk menentukan tingkat stres siswa menghadapi Ujian Nasional diteliti sejak tahun 2009 sampai sekarang. Penggunaan metode Iridologi menujuk- 
kan hasil yang positif. Tingkat atau level stres dapat diukur dan ditentukan serta diketahui perubahannya (menurun atau meningkat) Tulisan ini mencoba menjelaskan bagaimana metode Iridologi dapat digunakan dalam bidang pendidikan untuk menentukan tingkat stres siswa di SD, SMP, dan SMA.

Stres menjadi masalah masyarakat kita saat ini. Hal ini terjadi pada kalangan siswa SD, SMP, dan SMA di Sumatera Barat. Jika menjelang UN tingkat stres siswa dari tingkat SD, SMP, dan SMA meningkat. Penyebabnya adalah siswa tidak mampu mengembangkan cara belajar yang mandiri. Hal ini disebabkan rendahnya dayabaca siswa. Dayabaca juga tidak dilatih oleh guru di kelas sedini mungkin. Hal ini disebabkan oleh dayabaca atau kemauan membaca tidak dibina secara secara disiplin di sekolah. Sisi lain, guru secara umum memiliki daya baca yang rendah. Hal ini sering sekali diberitakan oleh media cetak maupun media elektronik seperti televisi.

Stres merupakan suatu kondisi fisik dan psikis yang terjadi akibat adanya tekanan atau faktor pemicu stres. Faktor pemicu stres beragam. Hal tersebut sangat dipengaruhi oleh sikap individu secara fisik dan psikologis dalam merespon interaksi yang terjadi dalam hidup dan kehidupannya. Praktisi ataupun ahli pendidikan sulit mendeteksi tingkat atau level stres yang mengenai siswa dari tingkat SD, SMP sampai SMA. Hal ini menyebabkan masalah stres saat akan mengikuti Ujian Nasional (UN) sulit dideteksi secara dini. Hal ini merupakan masalah yang perlu diatasi. Metode Iridologi dapat menjadi solusi dan mampu mendeteksi stres secara dini. Iris mata mampu menunjukkan tingkat stress yang diketahui secara Iridologi.

Iridologi adalah diagnosa iris atau selaput pelangi mata manusia yang mampu merefleksikan kondisi kesehatan tubuh dan emosi seseorang. Hal tersebut disebabkan iris mata manusia mengandung 28.000 saraf-saraf halus yang berhubungan dengan sel tubuh. Sarafsaraf halus tersebut mampu merefleksikan kondisi tubuh dan emosi seseorang (Jensen, 1982).

Seiring dengan perkembangan teknologi, iridologi mengalami perkembangan pesat sejak tahun 2000-an. Iridologi dikembangkan dengan menggunakan riset dan alat yang mampu menjelaskan kondisi tubuh manusia dan hewan secara dini. Iridologi sudah diaplikasikan di Indonesia pada hewan seperti ikan dan manusia dalam bidang kesehatan dan pendidikan.

Aplikasi Iridologi dalam bidang pendidikan telah diteliti sejak tahun 2009. Setelah itu, aplikasi Iridologi diteliti secara bertahap di SD dan SMP, pada tahun 2010 dan 2011.

Adapun tujuan penelitian ini adalah untuk mengidentifikasi tingkat stres siswa ketika akan menghadapi UN di SMA, SMP, dan SD dengan menggunakan metode Iridologi.

\section{METODE PENELITIAN}

\section{Waktu dan Tempat}

Penelitian ini dilaksanakan pada tanggal 1 November s/d 10 Desember 2009 di SMAN 2 Kab.Pesisir Selatan, 1 November 2010 di SDN 38 Kota Padang dan 1 Desember 2011 di SMPN 9 Kab.Sijunjung.

\section{Alat dan Bahan}

Alat penelitian ini adalah alat khusus Iridologi (Iriscope). Bahan berupa battery Alkaline AA 3 set dan buku berisi charta Iridologi dan determinasi gejala stres pada iris mata. Bahan berupa kertas HVS, bahan peragaan atau simulasi. 


\section{Cara kerja}

Kegiatan pengamatan iris mata siswa kelas III IPA, siswa VI SD dan siswa kelas III SMP. Iris mata kiri dan kanan siswa diperiksa jumlah archus atau lengkung stres pada iris mata. Jika makin banyak maka level stres makin tinggi jika hanya satu buah archuss tres maka level stres ringan atau jika tidak ditemukan berarti normal tanpa kondisi stres.
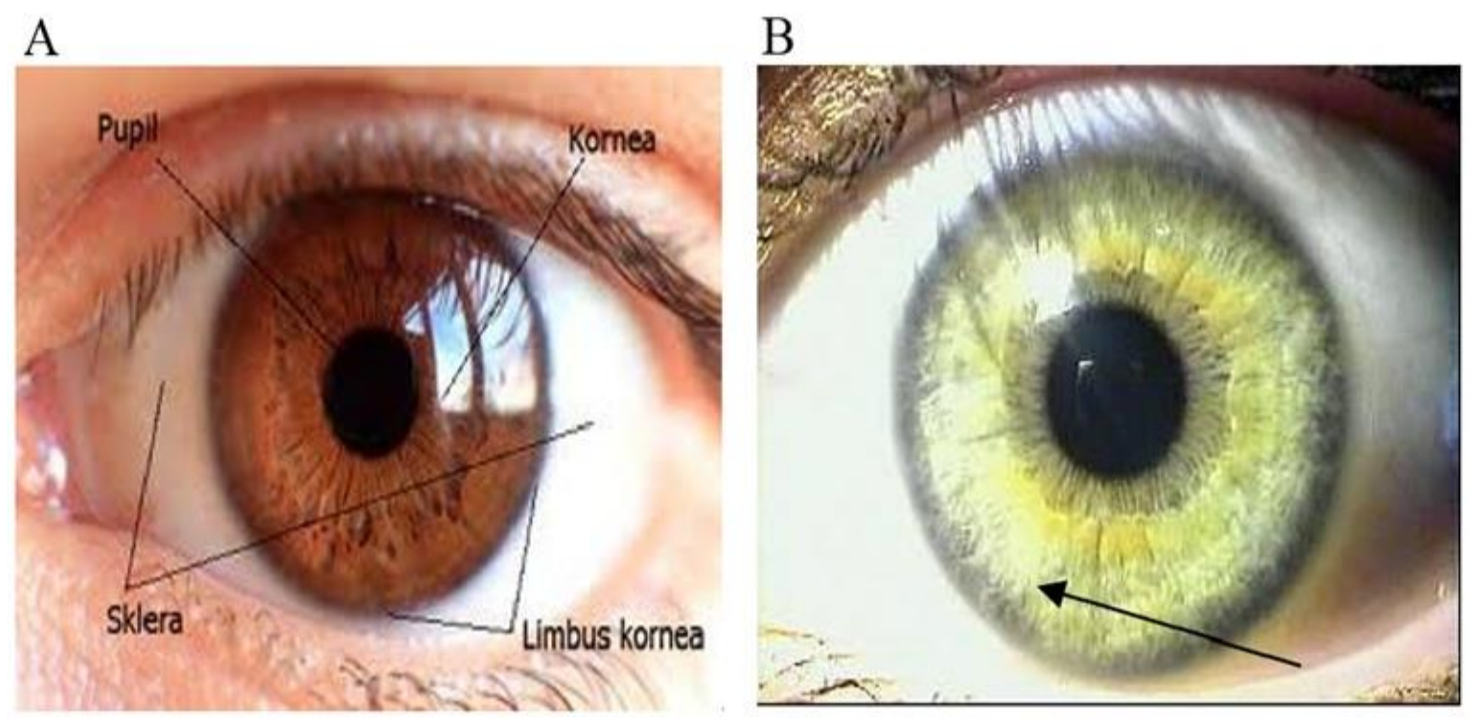

Gambar1. A. Bagian-bagian mata B. Iris mata manusia dengan lengkung stress

(Navratil, 2010)

\section{HASIL DAN PEMBAHASAN}

\section{SMAN 2 Kabupaten Pesisir Selatan}

Tabel 1 menunjukkan bahwa tingkat stres siswa SMAN 2 Kabupaten Pesisir Selatan berkisar sedang sampai tinggi. Dari 25 siswa yang diperiksa iris matanya 6 orang tinggi level stresnya, level sedang 19 orang dan tidak ada atau 0 orang level stresnya rendah atau $68 \%$ tingkat stress sedangdan $32 \%$ tingkat stress berat. Hal ini disebabkan beban belajar, tugas dan ujian nasional menjadi sesuatu yang menakutkan atau mencemaskan. Informasi tersebut diperoleh saat melakukan pengamatan iris mata siswa. Stres belajar telah mempengaruhi minat dan fokus siswa untuk belajar. Siswa merasa tertekan menghadapi UN. Sisi lain, para siswa kelas III IPA ini tidak mengetahui cara belajar efektif menghadapi UN (Nurainas, Razak dan Syamsuardi, 2010).

Tabel 1. Level Stres Siswa SMAN 2 Kabupaten Pesisir Selatan Menghadapi UN 2010

\begin{tabular}{|c|c|c|c|c|}
\hline \multirow{2}{*}{ No } & \multirow{2}{*}{ JUMLAH SISWA } & \multicolumn{3}{|c|}{ LEVEL STRES } \\
\hline & & TINGGI & SEDANG & RENDAH \\
\hline 1 & 25 ORANG & 6 ORANG & 19 ORANG & 0 ORANG \\
\hline
\end{tabular}




\section{SDN 38 Kota Padang}

Tabel 2 menunjukkan bahwa tingkat stres siswa SDN 38 Kota Padang berkisar rendah, sedang sampai tinggi. Hal ini disebabkan beban belajar, tugas dan ujian nasional menjadi sesuatu yang menakutkan atau mencemaskan. Informasi tersebut diperoleh saat melakukan pengamatan iris mata siswa adalah guru kurang sabar dan minim metode atau pendekatan saat mengajar. Hal ini membuat siswa stres dan juga cemas menghadapi UN. Di SDN 38 Kota Padang ini dari 37 siswa yang diperiksa iris matanya 9 orang tinggi level stresnya, level sedang 25 orang dan 3 orang level stresnya rendah. Prosentase tingkat stres ringan $0.08 \%$, tingkat stres sedang $65,7 \%$ dantingkat stress berat $24,3 \%$. Untuk mengatasi hal tersebut siswa diberikan motivasi dan pendekatan yang menyenangkan, hal ini akan memperkuat limbic (pusat kecerdasan otak manusia). Jika sistem limbic menguat berarti siswa merasa stabil atau nyaman siswa mengalami kondisi tanpa stres (Razak dan Rusdinal 2010).

Tabel 2. Level Stres Siswa SDN 38 Kota Padang

Menghadapi UN 2011

\begin{tabular}{cllll}
\hline \multirow{2}{*}{ No } & \multirow{2}{*}{ JUMLAH } & \multicolumn{3}{c}{ LEVEL STRES } \\
\cline { 2 - 5 } & SISWA & TINGGI & SEDANG & RENDAH \\
\hline \multirow{2}{*}{1} & 37 ORANG & 9 ORANG & 25 ORANG & 3 ORANG \\
\hline
\end{tabular}

\section{SMPN 9 Kabupaten Sijunjung}

Tabel 3 menunjukkan bahwa tingkat stres siswa SMPN 9 berkisar ringan, sedang sampai tinggi. Dari hasil pengamatan 34 orang siswa 11 orang dengan level stress tinggi, 20 orang level stress sedang dan 3 orang dengan level stress rendah. Prosentasenya tingkat stress ringan $0,8 \%$, tingkat stres sedang $59 \%$ dan tingkat stres berat $32 \%$. Hal ini disebabkan beban belajar, tugas dan ujian nasional menjadi sesuatu yang menakutkan atau mencemaskan. Hal yang menarik saat pengamatan iris mata, para siswa menyatakan mereka tidak makan pagi atau sarapan sehingga saat belajar mereka tidak fokus dan kurang energi. Hal ini menyebab kan lemahnya otak (limbic) mereka bekerja dan stres belajar telah mempengaruhi minat siswa untuk belajar. kondisi limbic siswa SMPN 9 pada taraf yang lemah. Sulitnya meningkatkan kondisi limbicsiswa kelas III SMPN Sijunjung ini akibat siswa tidak memiliki energi belajar yang cukup di pagi hari (Razak dan Rusdinal, 2011). Dari Tabel 1-3 menunjukkan bahwa iris mata dapat dibaca dengan metode Iridologi sebagai metode alternative mengukur level stress siswa menghadapi UN. 
Tabel 3. Level Stres Siswa SMPN Kabupaten Sijunjung Menghadapi UN 2012

\begin{tabular}{cllll}
\hline \multirow{2}{*}{ No } & \multirow{2}{*}{ JUMLAH SisWA } & \multicolumn{3}{c}{ LEVEL STRES } \\
\cline { 3 - 5 } & & TINGGI & SEDANG & RENDAH \\
\hline 1 & 34 ORANG & 11 ORANG & 20 ORANG & 3 ORANG \\
\hline
\end{tabular}

\section{PENUTUP}

Hasil penelitian menunjukkan bahwa metode Iridologi dapat menjadi alternatif menentukan tingkat stres yang ditunjukkan oleh data penelitian 20092011. Pengamatan iris mata pada penelitian selanjutnya didukung oleh alat yang lebih canggih agar pengamatan lebih mudah cepat dan akurat.

\section{DAFTAR RUJUKAN}

Nurainas, A. Razak dan Syamsuardi, 2010. Revitalisasi Motivasi Guru dan Siswa IPA SMA dengan Pendekatan Belajar Berbasis Otak untuk Meningkatkan Hasil Ujian Nasional (UN) di Sumatera Barat, Laporan Penelitian Hibah Kab. Kota 2009.

Jensen, B. 1982. Pelajaran Dasar Iridologi, PT. Bahana Mandiri Sentosa, Jakarta.

\section{UCAPAN TERIMA KASIH}

Terimakasih yang setinggitingginya kami ucapkan kepada Direktur Pascasarjana UNP dan jajarannya yang telah mendukung penulis dalam penelitian ini selama 3 tahun. Tak lupa kami ucapkan terimakasih kepada Dosen penulis, Pof. Syamsuardi dan Ibu Nurainas kolega kami dari Universitas Andalas.

Razak, A dan Rusdinal. 2010. Pengaruh Pelatihan Motivasi Berbasis Otak Terhadap Tingkat Stres Siswa Kelas VI SD Menghadapi UN 2011. Laporan Penelitian PPs.UNP 2010.

Razak, A dan Rusdinal. 2011. Pengaruh Pelatihan Motivasi Berbasis Otak Terhadap Tingkat Stres Siswa Kelas III SMP Menghadapi UN 2011. Laporan Penelitian PPs.UNP 2011. 